\title{
A critical review of current progress in 3D kidney biomanufacturing: advances, challenges, and recommendations
}

\author{
Nicholas M. Wragg ${ }^{1}$, Liam Burke ${ }^{2}$ and Samantha L. Wilson ${ }^{1 *}$ (D)
}

\begin{abstract}
The widening gap between organ availability and need is resulting in a worldwide crisis, particularly concerning kidney transplantation. Regenerative medicine options are becoming increasingly advanced and are taking advantage of progress in novel manufacturing techniques, including 3D bioprinting, to deliver potentially viable alternatives. Cell-integrated and wearable artificial kidneys aim to create convenient and efficient systems of filtration and restore elements of immunoregulatory function. Whilst preliminary clinical trials demonstrated promise, manufacturing and trial design issues and identification of suitable and sustainable cell sources have shown that more development is required for market progression. Tissue engineering and advances in biomanufacturing techniques offer potential solutions for organ shortages; however, due to the complex kidney structure, previous attempts have fallen short. With the recent development and progression of 3D bioprinting, cell positioning and resolution of material deposition in organ manufacture have never seen greater control. Cell sources for constructing kidney building blocks and populating both biologic and artificial scaffolds and matrices have been identified, but in vitro culturing and/or differentiation, in addition to maintaining phenotype and viability during and after lengthy and immature manufacturing processes, presents additional problems. For all techniques, significant process barriers, clinical pathway identification for translation of models to humans, scaffold material availability, and long-term biocompatibility need to be addressed prior to clinical realisation.
\end{abstract}

\section{Key points}

- Worldwide kidney shortages are driving the requirement for alternative approaches.

- The complex kidney microarchitecture and multiple cell types present engineering challenges which may be solved by 3D bioprinting.

- Despite advances in 3D bioprinting, the production of a functioning kidney remains elusive.

- It is imperative that developers consider the reliable, upscalable, and timely manufacturing processes.

\section{Introduction}

The need for modern, accessible, and feasible regenerative therapy solutions for the manufacture of human

\footnotetext{
* Correspondence: s.wilson2@lboro.ac.uk

${ }^{1}$ Centre for Biological Engineering, Wolfson School of Mechanical, Electrical and Manufacturing Engineering, Loughborough University, Epinal Way, Loughborough, Leicestershire LE11 3TU, UK

Full list of author information is available at the end of the article
}

organs has never been more significant, as the gap between organ need and availability continues to widen globally. This is despite significant efforts to educate the population in the importance of organ donation [1]. In 2014, a report into organ transplantation in the USA revealed kidneys as the most frequently transplanted organ with 15,978 operations, which is approximately 5000 more than all other organ transplants combined [2]. In the UK, kidneys are also the most in-demand organ, with more than 6500 people on a waiting list and 1 person dying almost daily whilst waiting [3]. The average waiting time for a kidney in the UK is 944 days [4], compared to 877 days in the USA [2]. During this time, if the kidneys enter renal failure, dialysis is required, either haemodialysis or peritoneal dialysis, whereby blood is diverted elsewhere to cleanse waste products before returning to the body. Dialysis is maintained until a suitable donor is found or, as is commonly the case, the patient passes away [5].

(C) The Author(s). 2019 Open Access This article is distributed under the terms of the Creative Commons Attribution 4.0 International License (http://creativecommons.org/licenses/by/4.0/), which permits unrestricted use, distribution, and 
Whilst whole organ transplantation has been considered a success in general, in lesser economically developed countries (LEDCs) such as Pakistan, India, and China, there are serious bioethical issues emerging. The limited supply of organs has resulted in trafficking and compensated donations, giving rise to criminal behaviour, growth of the 'black market', and medical tourism [6]. Despite the introduction of rigorous policing in LEDCs, and a drive for more donors in more economically developed countries (MEDCs) with a default 'deemed consent' or 'opt-out' laws on consent being implemented in many countries [7-10], these issues remain prevalent.

Therefore, for kidney failure, there currently exists very limited options: haemodialysis, peritoneal dialysis, kidney transplantation, or death. The aim of this review is to critically evaluate current research and explore treatment avenues required to fulfil patient duty of care, with a focus on 3D bioprinted and biomanufactured tissues and organs. Current barriers and limitations of bioengineered strategies will be discussed, and strategies to overcome these are suggested.

\section{Donor kidney characteristics}

The ideal kidney donor is described as a younger person who died from a traumatic brain injury leaving the thoracic and abdominal organ function free from injury/abnormalities [11]. Despite this, due to the number of recipients on the waiting list, older and 'less ideal' donors are utilised in ever increasing frequency [12]. Currently, the list of criteria of which a replacement must meet is extensive and based upon the social and medical history of the donor in addition to the blood type, crossmatch antibody test, and human leukocyte antigen (HLA) typing. These characteristics include age, history of hypertension or diabetes, potential of infectious disease transmission, cause of death, mechanism of death, anatomy of the allograft, morphology on biopsy, and functional profile prior to transplantation [11, 13]. Of course, kidneys can also be obtained from living candidates and they offer better graft function than deceased donor transplants [14]; however, at present, there exists no specific metric to which the quality of the kidney is measured, although risk indexes have been proposed and estimations of glomerular filtration rate (GFR), the flow rate of filtered fluid through the kidney, exist $[15,16]$.

\section{Risks and limitations of kidney transplantation}

Mounting research aimed at evaluating the risks of transplantation, for both living donor [17-19] and recipient [20-23], is giving cause for concern regarding current clinical interventions. Cancer is the third most common cause of death following kidney transplantation $[20,24,25]$, after organ rejection [26] and cardiovascular complications [27, 28], with higher cancer-related mortality rates for recipients compared to the general population [29]. An abundance of research has identified immunosuppression as the key factor increasing transplant mortality rates due to cancer [30], namely from interference in normal DNA repair mechanisms, whilst increased age, history of malignancy, and deceased donor transplantation further increase these rates [3133]. Immunosuppressant drugs are used immediately post-transplant to prevent the body rejecting or attacking the foreign organ, for example, mycophenolate mofetil (MMF) blocks, the proliferation of $\mathrm{T}$ and $\mathrm{B}$ cells which inhibit antibody formation and prevent the generation of cytotoxic T cells [31]. Despite increasing mortality, MMF is considered vital to transplant success and patient survival, with regimens lasting more than a year. However, risks are not exclusive to recipients; the major disadvantages to a living donor transplant are perioperative morbidity and mortality, and the long-term risk of living with one kidney, sometimes resulting in the donor becoming a transplant candidate following the development of renal failure at a later date [32]. Dialysis is not a viable alternative to enable long-term quality of life (QoL). Cardiovascular disease, including coronary artery disease, congestive heart failure, and pulmonary edema, along with erythropoietic and erythropoiesis deficiency, altered tissue oxygen delivery, increased and acute haemolysis, and associated bleeding and leukocyte abnormalities plus many more associated conditions occur directly as a result of dialysis and the wider influences of progressive renal failure [34-36]. This highlights the requirement for exploring alternative methods to reduce mortality, whilst aiding the global organ requirement.

\section{Regenerative therapy options for organ replacement}

Regenerative medicine replaces or regenerates human cells, tissues, and/or organs to restore or establish normal function [37]. In kidneys, this includes perfusion, filtration, secretion, and maintenance of homeostasis, with the ultimate aim of improving long-term patient QoL. Kidney research initially aimed to achieve this by targeting and improving dialysis.

\section{Cell-integrated and wearable artificial kidney devices}

Despite haemodialysis and peritoneal dialysis' ability to filter the blood, they fail to mimic the kidney's ability to secrete endocrine and immunologic factors, reabsorb, or metabolise [38]. A renal tubule assist device (RAD) containing human cells, developed by Humes et al., aimed to restore an element of immunoregulatory function [38-40] (Fig. 1a). In this, a synthetic hemofilter connects in-series with a bioreactor cartridge containing human proximal tubule cells grown to confluency within an extracorporeal circuit using standard hemofiltration pump systems. 


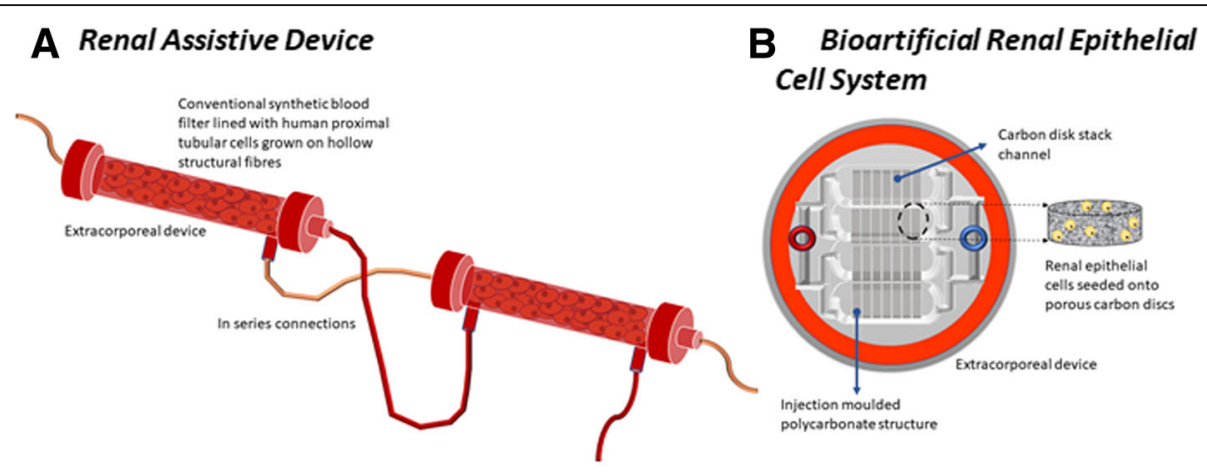

C Wearable Artificial Kidney
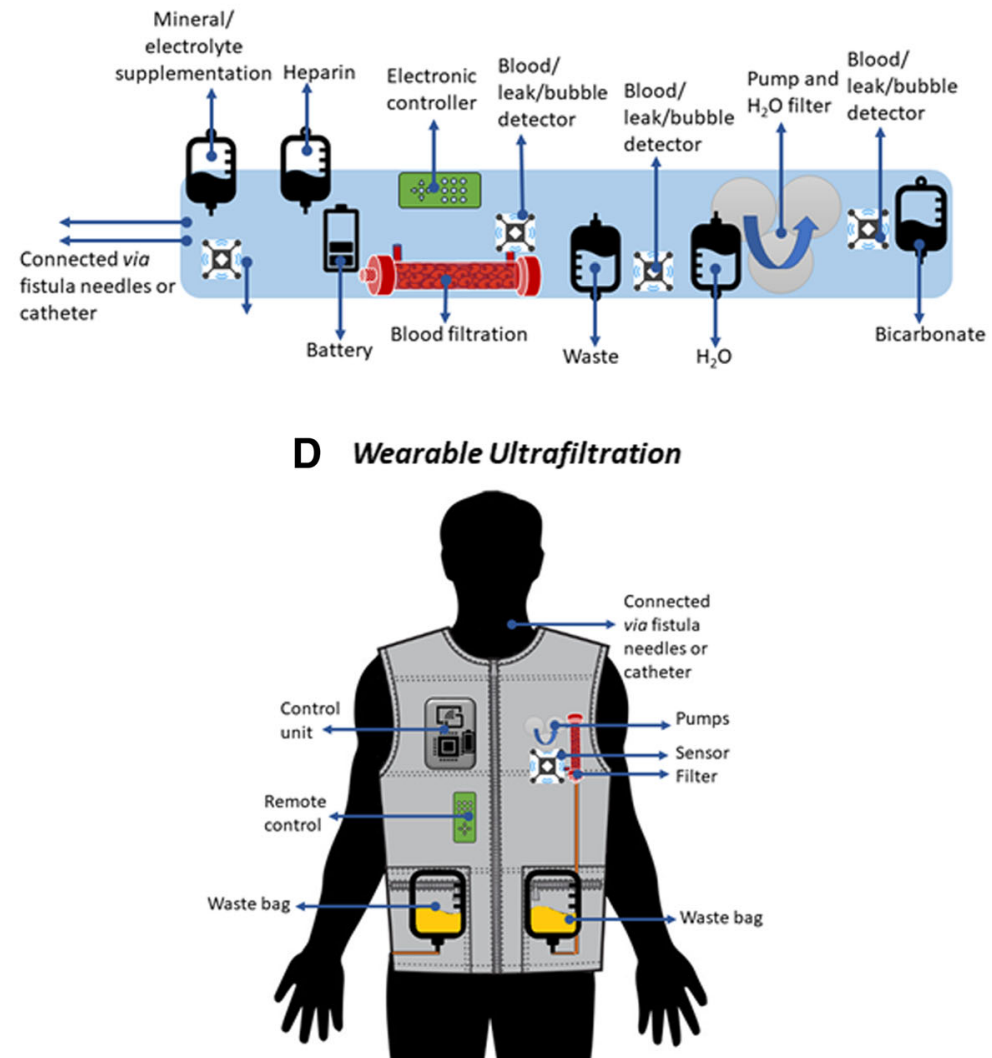

Fig. 1 Schematic representation of cell-integrated and wearable artificial kidney devices. a Renal assist device (RAD), an extra corporeal circuit with in series connections. b Bioartificial Renal Epithelial Cell System (BRECS), an extracorporeal filtration unit with renal epithelial cells seeded onto porous discs. c Wearable artificial kidney (WAK), concept designed to be a wearable, portable device. d Wearable ultrafiltration (WUF), concept designed to be discrete and wearable under garments

Human renal proximal tubule cells are immunologically active, which when adapted with non-biodegradable fibres, allows membranes to act as scaffolds for the cells and as an immunoprotective barrier which previous filtration methods lacked. Phase I/II clinical trials demonstrated that the RAD was able to filter urine at a rudimentary level, improve metabolism, reduce pro-inflammatory cytokines, and improve cardiovascular stability [40], whilst improving long-term survival [41].
Although RAD demonstrated that human proximal tubule cells could retain partial active transport properties and endocrine process activity, regeneration or restoration of previous functionality failed to improve for more than 24h [38-40]. Furthermore, RADs generated from discarded kidneys were limited to 4-5 units; with only 5-10 kidneys discarded per month, clinical demand could not be met [42]. Coupled with the expensive manufacturing process, in particular, the requirement to 
maintain the device at $37^{\circ} \mathrm{C}$, the fragile nature of the hollow structural fibres making it unsuitable for cryopreservation and the complexity of the system that required trained staff to maintain and operate it halted the progression of the RAD [42]. From these barriers and a suboptimal clinical protocol design, clinical trials were discontinued until these issues could be resolved [42].

The limitations of RADs led to a change of focus in the development of bioartificial kidneys (BAKs). Bioartificial renal epithelial cell systems (BRECS, Fig. 1b), an extracorporeal hemofiltration unit, aimed to overcome many of the manufacturing hurdles identified during the development of RADs. Specifically, to address issues of cell shortage, renal epithelial cell (REC) culture was optimised to generate suitable cell yields in order to meet clinical demand [43]. In addition, allogenic progenitor cells could also be harvested from suboptimal donors, including the elderly ( $>70$ years) and those with hypertension. RECs seeded onto porous niobium-coated carbon discs contained in a polycarbonate structure were shown to maintain both sterility and structural integrity following cryopreservation for up to 6 months creating a more economically viable process [42]. Although biologically successful, the specialised chamber manufacturing process for the initial BRECS unit was unsuitable for mass production [44]. Thus, injection moulding of medical grade polycarbonate was implemented as a technique to overcome this [45]. Although yet to advance from preclinical testing, BRECS is aimed at targeting both acute and chronic conditions, with ovine and porcine models demonstrating an improved therapeutic efficacy and prolonged survival in comparison to controls [46].

Continued research looks to develop a wearable battery-operated BRECS device, also referred to as a wearable artificial kidney (WAK, Fig. 1c) or wearable ultrafiltration (WUF, Fig. 1d) devices. With the rapid advances in microelectrical systems and nanotechnology, attaining mass manufacture may be achievable; however, consideration must be given to the life span and ability to replace or renew failed components with minimal intervention. The concept of a WAK is a small, portable device, worn as a utility belt that continually performs prolonged haemodialysis and removes urea [47]. They are usually connected to the bloodstream via a catheter or fistula needle, and unlike traditional dialysis treatments, WAKs can be worn continuously. Using a 2D transition metals (titanium), interweaved with carbides or nitrides, nanomaterials referred to as MXene sorbents can be used to remove urea [48]. Meng et al. demonstrated the efficient removal of urea, $94 \%$ at $30 \mathrm{mg} / \mathrm{dL}$, room temperature, with no reported cytotoxicity or biocompatibility issues [47].
The prevalent limitations of WAK and WUKs are the lack of vascular access whilst also retaining mobile and flexible properties [49]. Subcutaneous port devices [5054] have been proposed; these allow wearers to go about their daily activities, although future developments require miniaturisation and improved compatibility. $\mathrm{Hu}$ man clinical trials from 2016 demonstrated no cardiovascular disruption following $24 \mathrm{~h}$ continued use of WAK [55]. Castro et al. summarised future requirements for the development of WAK and WUFs. These include miniaturisation and improved portability of the pumping systems and dialysis membranes, improved replaceability of pumps and sorbent cartridges, remote patient monitoring systems, and increased battery life and removal of needles to improve the safety of connection/disconnection systems [49].

\section{Innate kidney repair and the influence of stem cells}

The kidney involves the complex interplay between 26 different cell types derived from the ureteric bud and metanephrogenic mesenchyme [56]. In view of this, many of these native cells have been suggested for use in repair/regeneration of kidneys [57, 58]. Intrinsically, kidneys can self-repair after injury to the tubules after injury by the proliferation and re-integration of tubular cells $[59,60]$. In 2003, Poulsom et al. described the influences of exogenous cell sources, specifically progenitor or 'Stem' cells (SCs) from sources such as bone marrow [59], in the repair of acute or extensive damage to the kidney's nephron. A review in 2009 by Hopkins et al. took this further and discussed the application of SCs in therapy to assist in the regeneration of kidneys [61]. It has since been posited that SCs interact to assist regeneration as mesenchymal stem cells or renal progenitor stem cells via secretion paracrine factors including extracellular vesicles (EVs) and growth factors [62-64]. Utilising the secretome in therapies, EVs in particular, has a distinct advantage over using cells. Extraction of the secretome from conditioned medium is more economical and practical than large-scale production and administration of stem cells [65]. Application of the secretome removes issues of immune compatibility, tumorigenicity, and infection transmission; it can be assessed similarly to current pharmaceutical agents; long-term storage without diminishing the potency can be achieved without common toxic cryopreservation agents, such as dimethyl sulfoxide (DMSO) [66-68]; and manufacturing schedules are significantly reduced in comparison to cell therapies. However, due to a cell's response to signalling affecting the composition of the secretome, producing an efficacious output is challenging $[64,69]$.

To recapitulate complex kidney function, epithelial, endothelial, and mesangial cells in sufficient numbers 
are required [41]. However, application of cell type is dependent upon the renal disease in question, therefore making it difficult to choose between tubular cells or glomerular epithelial cells, and research failed to identify whether it would be better to introduce progenitor cells for integration into existing structures or support cells which encourage existing renal parenchyma to proliferate and repair. Methods of injecting renal parenchyma were inconclusive as this only delivered cells into restricted regions of the kidney, making global integration unlikely; the diverse pathology of chronic kidney disease (CKD) made it likely that no one cellular therapy will be applicable to all conditions. For instance, the uremic state in CKD is toxic to somatic stem/progenitor cells and detrimentally impacts their differentiation and angiogenic potential [70]. Hopkins et al. hypothesised that renal cell differentiation from SCs would only be applicable if cells were seeded into a biodevice or used to create a replacement organ, such as in $3 \mathrm{D}$ organ printing [61].

As an alternative cell type, embryonic stem cells would also enable the formation of kidneys; however, amongst ethical, legal, and technical issues, injections of embryonic cells (ESCs) have been found to give rise to teratomas and are therefore less viable [71]. However, the use of induced pluripotent stem cells (iPSCs) can circumvent ethical issues presented by ESCs since they can be obtained from somatic cells. The high proliferative and differentiation capacity of pluripotent stem cells has meant that there has been a significant research focussed on the potential therapeutic benefit of iPSCs. However, caution should still be employed due to the presence of epigenetic memory [72, 73], and also, abnormal programming and the accumulation of somatic mutations may promote tumorigenesis and immunogenicity $[74,75]$.

\section{Tissue engineering and 3D organ printing}

Since the development of 3D printing in 1986 [76], the potential for healthcare applications has long been promoted and advances have seen the advent of bioprinting, in which solvent-free, aqueous-based systems enable direct printing of biological materials, including cells, into scaffolds, and thus, 3D bioengineering of organs has become a possibility [77]. Organ bioprinting has previously been defined as a layer-by-layer robotic biofabrication of 3D functional living macro-tissues and organ constructs using tissue spheroids as building blocks [78]. Mironov et al. identified three main steps to organ printing: developing blueprints to obtain a digital reconstruction of the natural form [78]; processing/printing using layer-by-layer placement of cells into a 3D environment either by droplet, dispensing, or stereolithography; and finally, perfusion and maturation of the printed organ post-processing.
The central challenge of organ printing is to reproduce the complex extracellular matrix (ECM) components with multiple cell types to recapitulate in vivo biological function [78]. In 2014, Murphy and Atala built upon Mironov et al.'s basic steps and proposed that successful organ printing may be achieved by consideration of the following approaches [79]: biomimicry, autonomous self-assembly, and mini-tissue building blocks. Successful biomimicry requires detailed replication of biological tissues, which relies upon the manufacture of physiologically accurate biomaterials, to achieve the functionality of natural processes. Autonomous self-assembly aims to replicate biological tissues based on the embryonic organ development process, whereby the early cellular components of a tissue produce their own ECM components, cell signalling, and organisation to achieve organ functionality [80]. This approach uses the cell to drive histogenesis, thus controlling the composition and functionality of the tissue $[79,81]$. The mini-tissues approach treats organs and tissues as a series of biological building blocks, viewed functionally as the smallest part of a tissue (e.g. a kidney nephron). Mini-tissues can be self-assembled, constructed as per a design, or both. For example, cell spheres can self-assemble into macro-tissues using biological design, or highly detailed reproductions of a tissue unit are designed and then allowed to self-assemble into a functioning macro-tissue $[78,82]$. These three approaches further expand to include six main steps of the 3D organ printing process: imaging, design, material selection, cell selection, printing, and application [79].

It should be recognised that bioprinting is still very much in its infancy [83]; despite this, such strategies have shown considerable progress and demonstrated great potential $[84,85]$. In the last 5 years, there has been a significant increase in the development and applications utilising this technology [86], including biosensors [87], proteins, and DNA arrays of stem cells [88].

\section{Current bioprinting methodologies and processes}

Murphy and Atala and Derakhshanfar et al. are comprehensive in their description of the current state of $3 \mathrm{D}$ organ printing, but the area remains largely conflicted, particularly regarding the hypothesised success of various printing methods [79, 89] (Fig. 2). For example, stereolithography has been depicted as a trailblazing technique due to its capability for printing intricate shapes and is reported to have $100 \mu \mathrm{m}$ resolution, with printing times of less than $1 \mathrm{~h}[90,91]$. Unfortunately, the fabrication process is cytotoxic and thus potentially detrimental to bioprinting [92] although the maintenance of high cell viability when seeded with cells has been reported [90, 91]. On the other hand, two-photon laser-based photo-crosslinking creates encapsulated 3D tissues rather than intricacies, but these can only be 


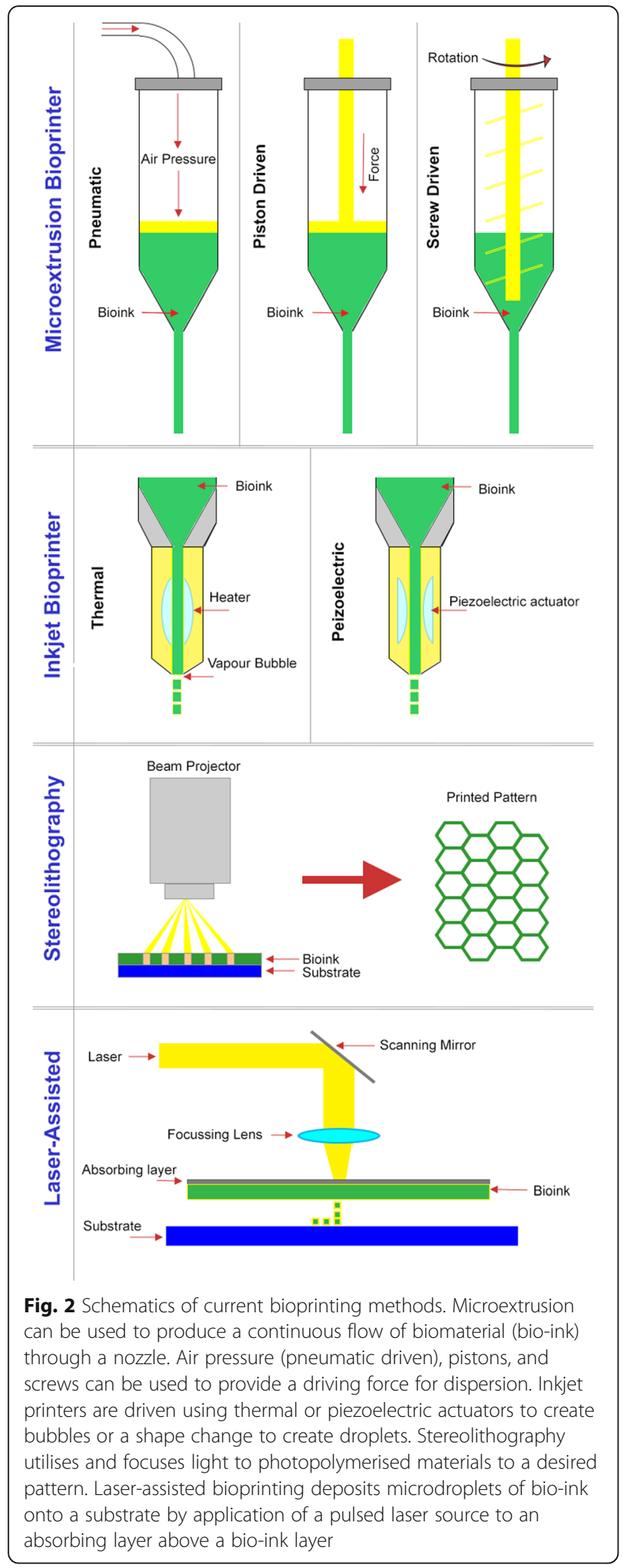

printed to several millimetres and are therefore clinically inappropriate [93].

Inkjet printers (or drop-on-demand printers) are the most commonly used biological printer, due to their low cost, wide availability, and high print speed [79]. However, they often suffer from mechanical stress, low droplet directionality, non-uniform droplet size, and nozzle clogging, thus making them unreliable for large-scale bioprinting applications [94]. Another limitation is that materials must be in liquid form to enable droplet formation before forming a 3D structure, which restricts the materials that can be applied using this technique. Khalil and Sun and Murphy et al. attempted to overcome this by crosslinking materials following deposition using chemical, $\mathrm{pH}$, or ultraviolet mechanisms, but this slowed the bioprinting process and altered ECM properties $[95,96]$. Analysing the success of the most common type of printer therefore emphasises two of the most difficult challenges which 3D bioprinting must overcome to become a success: obtaining a fast but reliable organ/ tissue manufacture speed, whilst developing highly specific biomaterials.

With life expectancy previously shown to be limited following a kidney transplant [29, 32, 33, 97], it is imperative that a method which can create a functioning kidney with a reliable, upscalable, and timely manufacturing process is developed so that patients can be given the greatest chance of recovery. However, the layer-by-layer approach to reproducing the intrinsic tissue microarchitecture requires more time as the complexity and number of components required increases. In addition, cell distribution throughout the organ and fabrication of the complex ECM microenvironment is of vital importance and can be addressed using bottom-up micro- and nanotechnologies [98] including self-assembly techniques and soft lithography [99-101], but further work is required.

Although a fully functional human kidney is yet to be developed, it is theorised that production will be highly time-consuming due to the complex and vital nature demanded of an organ. Whilst this impacts directly on patient waiting time, prolonged printing can also result in adverse effects on cell viability and the functionality of printed building blocks [14]. Hybrid tissue fabrication methods have shown great promise in developing intrinsically complex, cell encapsulated structures [102, 103] such as bespoke aortic valve conduits. The goal of creating a fully functioning organ currently remains elusive, and so a potential solution to elongated manufacturing times would be to simultaneous printing of different components of an organ by multiple printers or to combine techniques on a single printer; Shanjani et al. developed a hybrid printing system able to run dispensing and stereolithography simultaneously, but as in the 
aforementioned studies, the resulting constructs were small and clinically inadequate [104]. More recently, for vascularised heart engineering, Mauullari et al. developed a multi-cell dispensing process with an alginate and a polyethylene glycol monoacrylate-fibrinogen bio-ink extruding both induced pluripotent stem cell (iPSC)-derived cardiomyocytes and human umbilical vein endothelial cells (HUVECs) with a $\mathrm{CaCl}_{2}$ solution. However, this extrusion was through a single aperture and so precision from independent extrusion control of multiple extrusions was lacking. Multi-extrusion printers are available (e.g. 3Dynamic Systems' 3DS Omega Bioprinter [105]) although the resolution of printed material is generally not appropriate. Therefore, further research into combining techniques and increasing the scale of manufacture is required to explore this avenue further [106]. A review by Ozbolat et al. offers a more in-depth review of bioprinter technologies [107].

Alternative processes, such as laser-assisted printing, are expensive and complex; the slow processing and assembly time of current strategies, lasting from days to weeks, lend itself to reduced cell viability and tissue necrosis [79]. The protocols often require extensive multistep processes [108] with manual intervention; this in itself leads to the increased risk of errors whilst reducing reproducibility and scalability for manufacturing purposes. Bioprinting deposition does not in itself encompass the complete manufacturing process [109], requiring further maturation steps [84]. Moreover, there is a need to preserve and/or store organs if they are to be available off-the-shelf clinically. Currently, there are limited storage solutions for materials and bioprinted constructs [86]. Cryopreservation is the most promising avenue, but the literature of long-term storage of tissue-engineered constructs is considerably lacking.

\section{Bioprinting materials and structures}

When deciding upon the printing material, there are several considerations to be made, including printability, cytocompatibility, mechanics, degradation, bioactivity, functionalization capacity, biocompatibility, and bioactivity [110]. Bioprinted organs face the same issues regarding host rejection that both living and deceased donor transplants face, whereby there is a risk that the host's immune system will attack the foreign tissue [111, 112]. This highlights the importance of scaffold material biocompatibility to avoid host complications and/or rejection.

Many biomaterial ink formulations are currently unsuitable for cell printing $[113,114]$, since they require either elevated temperatures and dissolving solvents or a mixture of both. In incorporating a cellular structure within the printed construct, there is a need for the materials used to be more viscous and tuneable [115-118], whether this be via thermal or UV crosslinking [96, 119]. Whilst natural polymers including collagen and hyaluronic acid have good biocompatibility, they usually have poor mechanical properties; conversely, synthetic materials including polylactic acid and polyglycolic acid have good mechanical properties, but poor biocompatibility. To overcome this, a combination-material approach could be incorporated to meet the biomechanical requirements of the tissue/organ.

Novel bio-ink formulations are therefore required for each printing technology and strategy [120], since it is unlikely that no one ink will be compatible with all printing technologies and strategies.

In order to overcome microstructural difficulties, a modular approach can be adopted [121, 122], whereby smaller functional building blocks are assembled into biomimetic structures in a controlled manner. Nearly all organs and tissues require some form of vasculature for delivery of oxygen and nutrients and removal of waste. This microvasculature is currently lacking in bioprinted organs [123] and remains a major challenge to overcome [83] although progress is being made in some engineered tissues [124]. The use of in situ printing has been considered to overcome the problem of organ vascularization, although studies are currently limited [125]. This strategy encourages vessel sprouting from the endogenous tissue, which may be a solution if the organ to be replaced has retained functionality but may not be applicable for patients with acute kidney failure. A more appropriate approach may be to bioprint onto viable explants, although akin to in situ printing, studies presented in literature are currently limited [126]. The construction of channels into the interior of printed organs has also been investigated. The perfusion of nutrients into these channels may simulate vasculature, as can the addition of cells, although these structures are crude [123, 127-129] and further optimization of this process is required.

The layer-by-layer bioprinting process is not well suited to hollow structures; the resulting scaffold or construct often collapses, although the embedding of printed structures within a supporting to act as structural supports which can later be washed away has seen some success [130]; moreover, the mechanical properties in bioprinted kidneys are inferior in comparison to the native structures, leading to inaccurate structures when setting [86]. Sacrificial support materials can be employed to strengthen hollow scaffolds [127-132].

Researchers have had success in creating small organ models of a human kidney [133, 134] and heart [135] which are significant to disease modelling [136] and drugs and toxicity screening [137]. Unfortunately, the current limitations including the size of the structures mean that their lifespan is limited to days rather than 
years, which makes any estimation of appropriate scale model success speculative [1].

\section{Barriers to bioprinted kidney manufacture}

The process from identification of patient need to the printing of a new kidney can pose many barriers. With the addition of cells, these challenges further increase (Fig. 3). Furthermore, there are several technological challenges that are currently limiting the progress of bioprinted kidneys from proof-of-concept models to clinical realisation (Table 1). The largest hurdle is that there are currently no techniques capable of mimicking the multiscale, hierarchical architecture and complexity of the native tissue/organ $[108,122,138]$ which is vital to function. The minimum criteria for any kidney scaffold are that it is biocompatible, able to mimic the basic organ structure (including vasculature), be able to withstand forces caused by fluid flow whilst having filtration properties, is safe to use, and durable enough to be surgically handled whilst maintaining in vitro and in vivo integrity. Perfusion, filtration, secretion, absorption, and drainage of urine whilst maintaining homeostasis and control of hemodynamic, immunologic, and endocrine functions are also important factors [41]. Other obstacles include the lack of high-resolution cell deposition [139], controlled cell distribution, vascularization [110], and innervation. Cell viability of printed organs is highly variable, with the side effects on the cells when using the various techniques unknown. The in vivo functionality and biocompatibility of printed organs and tissues remain largely unknown, with large variations in published animal studies [108]. Once printed control of cell phenotype and fate can be regulated via biological and physical factors including the use of growth factors [140], shear stress [141, 142], electrical stimulation [123, 143, 144], and mechanical cues, but these will need to be investigated in a systematic series of experiments.

\section{Cell sources for kidney bioprinting}

The model cell source for kidney regeneration has yet to be determined. Ideally, cells should be readily available, easy to expand in culture, remain viable and functional, be non-immunogenic, and able to reproduce all functions of the kidney in order to be viable for bioprinting [79]. Since there are over 20 distinct cells in the kidney, it is unsurprising that regeneration of all types has yet to be achieved.

To begin to achieve this, autologous cells are usually obtained from biopsies or from the generation and differentiation of autologous SCs. Limitations of this approach, however, occur if the host is ill or suffering from genetic or metabolic disorders or renal failure [145], as it may not be viable to perform invasive surgical procedures. Human primary cells are difficult to expand and maintain, possessing a finite lifespan, making long-term functionality unlikely for bioprinted organs in the current state of the field [146]. Furthermore, isolated cell types from adult kidneys undergoing in vitro expansion and manipulation may not function as normal, losing their differentiated phenotype [147]. It is speculated as to whether this is due to the terminally differentiated cells being forced into a proliferative state, due to a lack of inherent cues, or a combination of both.

In vivo cells are reliant upon fluid mechanical cues including shear stress, tension, compression [138, 148], and biomolecular gradients for normal functionality. By gaining an understanding of embryonic development, this allows for the mechanisms that regulate the

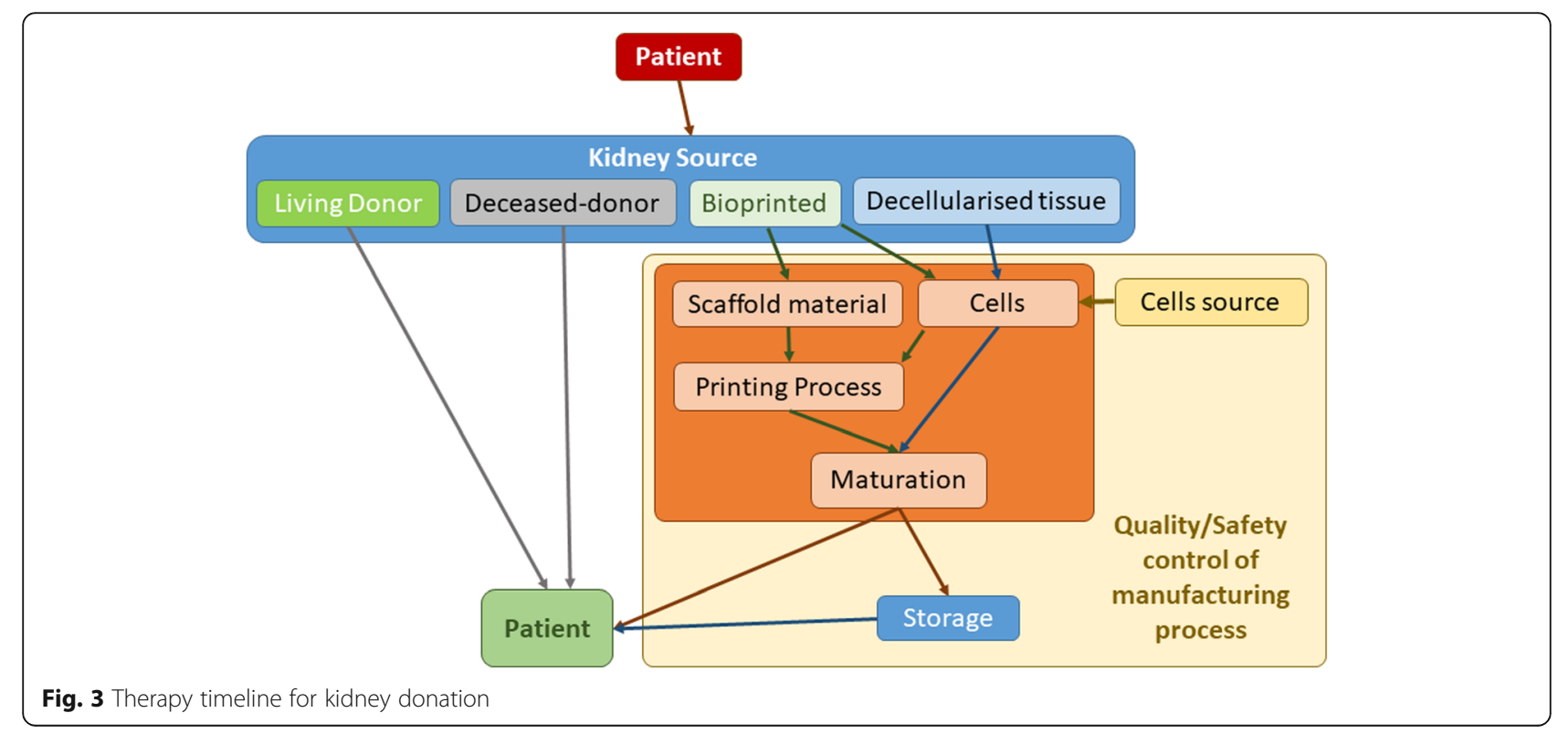


Table 1 Critical Criteria for 3D printing

\begin{tabular}{ll}
\hline Criteria & Specific parameters \\
\hline Cell source & - Inclusion of multiple cell types \\
- Biocompatible & - Mechanically biomimetic \\
& $\circ$ Able to withstand fluid flow forces \\
& - Safe \\
& - Durable \\
& $\circ$ Able to be handled and maintained in vitro and \\
& in vivo \\
& - Multiscale \\
& - Hierarchical \\
& - Perfusion, filtration, secretion, absorption, and \\
Structure & drainage of urine \\
- Maintenance of homeostasis & - Control of functions: \\
& $\circ$ Hemodynamic \\
& $\circ$ Immunological \\
& $\circ$ Endocrine \\
& • High-resolution cell deposition \\
& - Controlled cell distribution \\
& - Inclusion of: \\
& $\circ$ Vascularisation \\
Mrocess &
\end{tabular}

induction of collecting ducts versus kidney mesenchyme to be unpicked. In vivo, the metanephric mesenchyme generates the majority of kidney components including the vascularised glomeruli with podocytes, proximal and distal tubules, and lumina [149]. The majority of the epithelial cells are located in the nephron derived from multipotent progenitor cells in the metanephric cap [150-153] with the exception of those in the collecting ducts. To recapitulate this dynamic environment in vitro is extremely demanding [154]. 3D cell cultures, including suspension cultures [155], have shown more promise in comparison to monolayer cultures, although often inadequate cell sources have limited whole organ bioengineering [147]. Cellular cultures with a mechanistic approach allow for the generation of nephron-containing organoids, surrounded by renal interstitium and endothelial cells that are comparable to human foetal tissues [156]. Although such structures may currently be more applicable to disease and nephrotoxicity modelling, they may also serve as a source for cellular therapy and tissue engineering applications.

SCs are a promising alternative for fulfilling the shortcomings of human primary cells due to their ability to proliferate in an undifferentiated but multipotent state, as well as being able to generate multiple tissue-specific cell phenotypes. It is theorised that combinations of mature cell sources can be applied to reproduce the phenotypes required in a stable construct. Adult SCs derived from functional tissue components could be used to generate the building blocks of the organ construct, while MSCs derived from bone marrow or gestational tissue could generate the connective tissue required for the structural components of the organ [79]. Other types of stem cell, such as perinatal SCs from amniotic fluid or placenta, and iPSCs are thought to have a lesser multipotent differentiation potential but are considered safer and more ethically acceptable, therefore perhaps providing a temporary solution, allowing research to progress at a limited capacity $[157,158]$.

Induced PSCs have successfully been generated from cells of renal origin including mesangial, tubular epithelial cells and renal epithelial cells [159-163]. Tajiri et al. also demonstrated that it is possible to generate iPSCs from peripheral blood mononuclear cells (PBMCs) from patients undergoing dialysis due to diabetic nephropathy and glomerulonephritis [70]. The study presented that protein and marker expression and nephron progenitor cell (NPC) derivation were similar to healthy controls. This may present a promising tool for personalised kidney regeneration, although the study was limited to three patients (with two control patients) and the efficacy was variable [70]. Also, further characterisation of these generated nephrons is required to determine long-term efficacy.

The differential induction of NPCs and ureteric buds has also been recently reported using multistep culture conditions on both mouse ESCs and human-induced pluripotent stem cells (iPSC) [149, 154, 164]. Protocols have been developed to mimic the physiological conditions during the development of metanephric progenitors to produce cells capable of establishing 3D nephric tubules and glomeruli. Published protocols are chemically defined, utilise low doses of fibroblast growth factor-8 (FGF8, $10 \mathrm{ng} / \mathrm{mL}$ ) and CHIR to define anterior-posterior patterning, and suppress bone morphogenic protein 4 (BMP4) using Noggin in 3D suspension cultures to direct differentiation of iPSCs and ESCs [155]. In 2015, Takasato et al. published methods to modulate the introduction of two intermediate mesoderm-derived progenitor populations [156]. They utilised phasic Wnt stimulation and growth factors to promote metanephric mesenchyme development from iPSCs. However, full functionality may be lacking, since in vitro recapitulation of inter-nephron connections by the collecting ducts was lacking. A selective induction method was used by Taguchi et al. to improve the embryonic branching morphogenesis of epithelial tissue, a prerequisite of renal drainage systems [154]. This was an attempt to reconstitute higher-order organ structure and to support a model for kidney lineage specification. Although Morizane et al. generated NPCs from iPSCs 
more efficiently compared to Taguchi et al., the NPCs in Taguchi's protocol were capable of interacting with both the uretic buds and glomeruli to attract blood vessels in vivo [154]. Mae et al. investigated the selective differentiation of uretic buds (renal progenitors) using iPSCs and hESCs; however, the differentiation process mechanisms have yet to be ascertained [164]. Despite robust protocols being devised, none yet are at the stage of generating fully functioning tissues or reliable, upscalable processes for the generation of renal cells for bioengineering. In order to realise this potential, there is still a requirement to devise expansion culture methods and the capability to achieve high throughput, efficient, rapid, reliable, and robust means of detecting cell differentiation [165]. The generation of functional kidney tissue from PSCs and iPSCs may allow for the development of cellular therapy treatments in the future.

It should be considered that current bioprinting techniques including extrusion, inkjet, and stereolithographic methods either reduce cell viability or have unknown consequences on cell fate [79, 108, 166]. Furthermore, reliable cell sourcing and printing of primary cells increase the complexity of the processes [86]. Porous scaffolds, similar to hollow scaffolds, often suffer from uncontrollable geometry and the risk of damage to the encapsulated cells [86]; similarly, inkjet printers, particularly when used with highly viscous polymer solutions, may clog [110, 167-170].

Currently, there are no regulatory approved cellular treatments for kidney disease despite numerous clinical trials being undertaken. Stem cells isolated for the bone marrow of the kidney donor have been investigated in conjunction with alemtuzumab (Campath, Lemtrada) as a preventative treatment for organ rejection. However, the addition of bone marrow stem cells (BMSC) failed to induce tolerance, with graft failure occurring in two of the four patients treated and graft loss in the third patient [171]; thus, the trial was terminated.

Bioprinting alternatives: self-assembling organoid formation Although complete kidney regeneration using SCs remains elusive, small yet complex kidney structures with renal-specific functions, referred to as organoids, have been developed as a way of potentially replacing renal function [75]. Organoids are capable of spontaneous organisation into structures resembling nephron segments, glomeruli, interstitium, and collecting ducts [149, 154, 156, 172-174] akin to the embryonic kidney. However, the nephrons within current organoids are not fully differentiated and lack vital vasculature [165].

Since kidney organoids are predominantly comprised of a single cell type in a 3D matrix, they are currently limited to the study of kidney disease and injury [175-177], drug nephrotoxicity [178, 179], and kidney development [156, 172], since they are incapable of replicating the varied functionality of a kidney. Thus, the ability to restore renal structures and engineer new kidney tissues remains extremely ambitious [75], not least since the kidney is inherently unable to regenerate new nephrons in vivo. Despite this, iPSC-derived organoids may potentially be utilised in alternative bioengineering approaches; distinct renal cells isolated from iPSC kidney organoids may be useful for generating sufficient numbers of cells for populating biologic or artificial tissue scaffolds and matrices [165].

\section{Tissue decellularization}

Harvested kidneys do not always meet the quality control criteria for transplantation [147]; thus, the use of decellularized kidneys are a promising alternative approach [110], since these strategies have the potential to achieve a matrix that more closely resembles the native tissue. Decellularization as a process aims to remove residual cellular material whilst preserving the native structure, protein ratio, and location of inherent biological cues including glycosaminoglycans (GAGs), proteins including collagen I and IV, laminin, and fibronectin [180] to retain in vivo-like function and proliferation following reseeding [181, 182]. These factors may help promote and support multiple cell types and thus provide efficient and effective kidney regeneration [56]. Cellular material and immunogens must be eliminated since they may initiate inflammatory response [183], ultimately leading to immune rejection following transplantation. Chemical and physical cues are vital for cellular growth and expansion. GAGs bind growth factors and thus are important for prolonged growth and differentiation; they also retain water in the ECM and so are important for maintaining the gel-like properties of the ECM [184]. It is not only the inclusion of factors, but also the distribution that are important for cell homing and differentiation [183]. Potent growth factors including fibroblast growth factor (FGF), hepatocyte growth factor (HGF), vascular endothelial growth factor (VEGF), and interleukin-8 (IL-8) are all important for cellular fate and growth [57, 185]. Insulin-like growth factor (IGF), HGF, and FGF-9 are all crucial for kidney-specific gene expression $[25,172,186]$.

Kidney decellularization success is often reliant upon the organ harvest, which must have occurred prior to proteolysis (4-6 h post-mortem) [41], and the age of the kidney has also been shown to have an effect on cellular repopulation [187]. Xeno matrices, including the use of porcine tissues, have also been investigated to reduce some of these barriers [183, 188, 189], since the organ size is comparable to humans [190-193] and porcine matrices are able to promote the adhesion, survival, and maintenance of human cells [180, 194-196]. However, 
for decellularization to be a viable starting point, there is a need to standardise decellularization processes and consider the manufacturing challenges including scalability, sterilisation, and preservation. Once processed and dependent upon the application, decellularized matrices may be utilised in one of two ways: acellular constructs to be cellularized by the recipient or reseeding of the construct. In the case of kidney, the goal is to provide a cellularized construct viable for transplantation.

Preservation of critical microstructure and intact vasculature are essential for successful recellularization [183]. The glomeruli and renal structures in particular are prone to damage due to high perfusion pressure applied during some decellularization processes [183]. Reseeding protocols have often proven to be problematic. Cannulation can be employed to recellularize the kidney vasculature, although recellularization of the collecting ducts poses a significant challenge [147]. Cellular delivery via the renal artery and ureter has been investigated in rat studies [197]. This permits delivery via the existing vasculature and collecting system, respectively, with viable cells detected in the vascular and glomerular networks [198], although seeding of the tubules poses more of a challenge. Song et al. were one of the first groups to transplant reseeded kidney transplants into nephrectomised rats [58]. However, a lack of glomeruli maturity meant that the constructs were unable to restore kidney-specific parameters. Similarly, Guan et al. demonstrated that despite the initial acceptance of reseeded kidney scaffolds, insufficient blood supply due to thrombosis in the renal artery and rein resulted in transplant failure [199]. This was thought to be due to incorrect cell differentiation of cells populating the vasculature.

Detergents sodium dodecyl sulphate (SDS) and Triton-X100 are commonly utilised for kidney decellularization via renal artery perfusion methods. Despite reports of success in the removal of cellular material and maintenance of the kidney structure and biological cues, many protocols fail to look at the ECM regions in any detail [180]. The process itself inevitably causes alterations to the ECM topography and biochemistry. O'Neill et al. performed a porcine study and determined that sulphated GAG composition was variable in kidney sections and was often lower in the cortex [200]. Microstructural architectural disturbances can have a direct impact on cell morphology, phenotype, and organisation in addition to detrimentally affecting the organ biomechanical properties, which often go untested.

Residual decellularizing agents such as the detergents SDS and Triton-X100 are notoriously difficult to eradicate and can cause the failure of subsequent cell application. This is due to their cytotoxic properties and capacity to denature proteins, causing a loss of functionality if exposure is too long [195]. Despite this, often any detail regarding testing of residual decellularizing agents is not included in published literature. Currently, it is the inability to effectively differentiate reseeded cells that is hampering the success of reseeded kidney constructs. Thus, there is a need to understand the specific signalling pathways and growth factor combinations to guide differentiation. Furthermore, decellularizing agents may alter tissue-specific cell adhesion sites, thus impeding their growth and/or causing changes to genotype and phenotype [190].

\section{Strategies to address current limitations}

In order to realise the potential bioengineering, including the use of bioprinting for closing the organ donor gap, there is a need for innovative thinking, which encompasses scalability of current technologies and novel printing methodologies, whilst also accounting for cost-effectiveness. Currently, the biggest hurdle to overcome is the requirement of faster printers capable of higher resolution, than is currently available. Rather than attempting to optimise a single manufacturing process for the creation of a fully functioning kidney, the best approach may be to combine techniques to recreate the structural heterogeneity, tissue hierarchical structure, and functionality.

There is also a need for post-printing maturation of printed tissues under physiological conditions [109] which could be met via the use of bioreactors, or in vivo maturation, although this would require the native tissue to be non-vital and not completely dysfunctional [109]. Researchers should be working alongside regulators from the outset when developing any bioprinted organ to facilitate clinical realisation and translation.

The most likely application for bioprinted organs in the near future is the use of mini-tissues [201] for use in prostheses, predicting therapeutic and/or toxic responses [86, 202], whilst potentially decreasing the costs of novel drug discovery and increasing the understanding of disease mechanisms $[99,115,203]$, whilst decreasing the reliance upon animal models [201]. It is likely that cellular therapies that promote natural repair pathways will reach clinical realisation prior to cell replacement therapies although supramolecular hydrogels with reversible crosslinking [204] and stimulus-responsive materials for biomimetic 4D printing [205] are beginning to show promise in the potential for augmented grafting which could offer a bridge towards whole organ engineering.

\section{Conclusion}

A review of current regenerative research demonstrates that work to advance 3D organ printing is abundant, but thus far falling short of providing a solution to current 
organ crises especially in the case of kidney transplantation. The main issues preventing functional human kidney constructs being developed are slow manufacture time, clinically inadequate printing methods, and biomaterial availability and ethicality. Innovative new printing methods are being designed, which incorporate some hybrid techniques, but do not yet combine multiple processes to manufacture whole kidney structures. This is limited by the relative infancy of the field and is still at a fundamental stage rather than translational. Current research has, however, advanced in understanding which cell types are viable for specific organ components (e.g. functional tissue-derived SCs for tissue construction and bone marrow-derived mesenchymal stem cells (MSCs) for component connection. The central challenge of 3D organ printing is to reproduce the complex microarchitecture of ECM components and multiple cell types in sufficient resolution for normal biological function, and the current research indicates we are unable to do this adequately enough for clinical trials to go ahead at this stage, meaning that the kidney crisis faces further uncertainty in the near future.

\begin{abstract}
Abbreviations
BAK: Bioartificial kidney; BMSC: Bone marrow stem cell; BRECS: Bioartificial Renal Epithelial Cell System; CKD: Chronic kidney disease; DMSO: Dimethyl sulfoxide; ECM: Extracellular matrix; ESC: Embryonic stem cell; EV: Extracellular vesicle; FGF: Fibroblast growth factor; GAG: Glycosaminoglycan; GFR: Glomerular filtration rate; HGF: Hepatocyte growth factor; HLA: Human leukocyte antigen; HUVEC: Human umbilical vein endothelial cell; IGF: Insulinlike growth factor; IL-8: Interleukin-8; iPSC: Induced pluripotent stem cell; LEDC: Lesser economically developed country; MEDC: More economically developed country; MMF: Mycophenolate mofetil; MSC: Mesenchymal stem cell; NPC: Nephron progenitor cell; PBMC: Peripheral blood mononuclear cell; QoL: Quality of life; RAD: Renal assistive device; REC: Renal epithelial cell; SC: Stem cell; SDS: Sodium dodecyl sulphate; VEGF: Vascular endothelial growth factor; WAK: Wearable artificial kidney; WUF: Wearable ultrafiltration
\end{abstract}

\section{Acknowledgements}

Not applicable

\section{Availability of data and material}

Not applicable

\section{Funding}

There is no funding associated with this publication.

\section{Authors' contributions}

NMW significantly contributed to the research, writing, production of figures, and editing of this manuscript. LB significantly contributed to the research and writing of the manuscript. SLW significantly contributed to the research and writing and undertook substantial reviewing and editing of the manuscript. All authors read and approved the final manuscript.

\section{Ethics approval and consent to participate}

Not applicable

\section{Consent for publication}

Not applicable

\section{Competing interests}

The authors declare that they have no competing interests.

\section{Publisher's Note}

Springer Nature remains neutral with regard to jurisdictional claims in published maps and institutional affiliations.

\section{Author details}

${ }^{1}$ Centre for Biological Engineering, Wolfson School of Mechanical, Electrical and Manufacturing Engineering, Loughborough University, Epinal Way, Loughborough, Leicestershire LE11 3TU, UK. ${ }^{2}$ National Centre for Sport and Exercise Medicine, School of Sport, Exercise and Health Sciences, Loughborough University, Epinal Way, Loughborough, Leicestershire LE11 3TU, UK.

Received: 19 March 2019 Accepted: 25 April 2019

Published online: 09 May 2019

\section{References}

1. Jain A, Bansal R. Applications of regenerative medicine in organ transplantation. J Pharm Bioallied Sci. 2015;7(3):188-94.

2. Alachkar N, Rabb H, Jaar BG. Urinary biomarkers in acute kidney transplant dysfunction. Nephron Clin Pract. 2011;118(2):173-81.

3. NHS NHSB and T. Highest number of organ transplants ever across UK, but many families still say no to donation - NHS Organ Donation Register | Organ Donation - English. 2016. Available from: https://www. organdonation.nhs.uk/news-and-campaigns/news/highest-number-oforgan-transplants-ever-across-uk-but-many-families-still-say-no-to-donation/. Cited 3 Jan 2019.

4. NHS NHSB and T. Waiting time to kidney transplant down $18 \%$ but shortage of donors still costing lives - NHS Organ Donation Register | Organ Donation - English. 2017 Available from: https://www.organdonation.nhs. uk/news-and-campaigns/news/waiting-time-to-kidney-transplant-down-18but-shortage-of-donors-still-costing-lives/. Cited 2019 Jan 3

5. NHS NHS. Dialysis - NHS. 2018 .Available from: https://www.nhs.uk/ conditions/dialysis/. Cited 2019 Jan 3

6. Korol RL, Milner KS, Running SW. Testing a mechanistic model for predicting stand and tree growth. For Sci. 1996;42(2):139-53.

7. NHS, National Health Service B and T. The opt-out system - NHS Organ Donation Register | Organ Donation - English.2018. Available from: https:// www.organdonation.nhs.uk/supporting-my-decision/the-opt-out-system/. Cited 2019 Jan 4

8. Department of Heath and Social Care. Consultation on introducing 'opt-out' consent for organ and tissue donation in England - GOV.UK. 2019. Available from: https://www.gov.uk/government/consultations/introducing-opt-outconsent-for-organ-and-tissue-donation-in-england/consultation-onintroducing-opt-out-consent-for-organ-and-tissue-donation-in-england. Cited 2019 Jan 4

9. Saab S, Saggi SS, Akbar M, Choi G. Presumed consent: a potential tool for countries experiencing an organ donation crisis. Dig Dis Sci. 2018;64(5): 1346-55.

10. Wilson L, Carter A. Organ donation. Br J Hosp Med. 2018;79(1):C8-12.

11. Metzger RA, Delmonico FL, Feng S, Port FK, Wynn JJ, Merion RM. Expanded criteria donors for kidney transplantation. Am J Transplant. 2003;3(Suppl 4): 114-25.

12. Kauffman HM, Bennett LE, McBride MA, Ellison MD. The expanded donor. Transplant Rev. 1997;11(4):165-90.

13. Gozdowska J, Jankowski K, Bieniasz M, Wszoła M, Domagała P, Kieszek R, et al. Characteristics of potential living kidney donors and recipients: donor disqualification reasons - experience of a polish center. Transplant Proc. 2013;45(4):1347-50.

14. Park JH, Jang J, Lee JS, Cho DW. Three-dimensional printing of tissue/organ analogues containing living cells. Ann Biomed Eng. 2017;45(1):180-94.

15. Massie AB, Leanza J, Fahmy LM, Chow EKH, Desai NM, Luo X, et al. A risk index for living donor kidney transplantation. Am J Transplant. 2016;16(7): 2077-84.

16. Levey A, Inker L. Assessment of glomerular filtration rate in health and disease: a state of the art review. Clin Pharmacol Ther. 2017;102(3):405-19.

17. Maggiore U, Budde K, Heemann U, Hilbrands L, Oberbauer R, Oniscu GC, et al. Long-term risks of kidney living donation: review and position paper by the ERA-EDTA DESCARTES working group. Nephrol Dial Transplant. 2017; 32(2):216-23.

18. Matas AJ, Hays RE, Ibrahim HN. Long-term non-end-stage renal disease risks after living kidney donation. Am J Transplant. 2017;17(4):893-900. 
19. Janki S, Steyerberg EW, Hofman A, IJzermans JNM. Live kidney donation: are concerns about long-term safety justified? - a methodological review. Eur J Epidemiol. 2017;32(2):103-11.

20. Yanik EL, Gustafson SK, Kasiske BL, Israni AK, Snyder JJ, Hess GP, et al. Sirolimus use and cancer incidence among US kidney transplant recipients. Am J Transplant. 2015;15(1):129-36.

21. Bodro M, Sanclemente G, Lipperheide I, Allali M, Marco F, Bosch J, et al. Impact of antibiotic resistance on the development of recurrent and relapsing symptomatic urinary tract infection in kidney recipients. Am J Transplant. 2015;15(4):1021-7.

22. De La Mata N, Masson P, Al-Shahi Salman R, Kelly P, Webster AC. Stroke mortality in kidney transplant recipients. Transplantation. 2018;102:S423-4.

23. Allen PJ, Chadban SJ, Craig JC, Lim WH, Allen RDM, Clayton PA, et al. Recurrent glomerulonephritis after kidney transplantation: risk factors and allograft outcomes. Kidney Int. 2017;92(2):461-9.

24. Sprangers B, Nair V, Launay-Vacher $V$, Riella LV, Jhaveri KD. Risk factors associated with post-kidney transplant malignancies: an article from the Cancer-Kidney International Network. Clin Kidney J. 2018;11(3):315-29.

25. Kang W, Sampaio MS, Huang E, Bunnapradist S. Association of pretransplant skin cancer with posttransplant malignancy, graft failure and death in kidney transplant recipients. Transplantation. 2017;101(6):1303-9.

26. Bhatti $A B$, Usman $M$. Chronic renal transplant rejection and possible antiproliferative drug targets. Cureus. 2015;7(11):e376-91.

27. Neale J, Smith AC. Cardiovascular risk factors following renal transplant. World J Transplant. 2015;5(4):183-95.

28. Lam NN, Kim SJ, Knoll GA, McArthur E, Lentine KL, Naylor KL, et al. The risk of cardiovascular disease is not increasing over time despite aging and higher comorbidity burden of kidney transplant recipients. Transplantation. 2017;101(3):588-96.

29. Hall EC, Engels EA, Pfeiffer RM, Segev DL. Association of antibody induction immunosuppression with cancer after kidney transplantation. Transplantation. 2015;99(5):1051-7.

30. Sellarés J, de Freitas DG, Mengel M, Reeve J, Einecke G, Sis B, et al. Understanding the causes of kidney transplant failure: the dominant role of antibody-mediated rejection and nonadherence. Am J Transplant. 2012; 12(2):388-99.

31. Muntean A, Lucan M. Immunosuppression in kidney transplantation. A short history of immunosuppression in kidney transplantation. Rev Clujul Med. 2013;86(3):177-80

32. Matas AJ, Bartlett ST, Leichtman AB, Delmonico FL. Morbidity and mortality after living kidney donation, 1999-2001: survey of United States transplant centers. Am J Transplant. 2003;3(7):830-4.

33. Ellison MD, McBride MA, Taranto SE, Delmonico FL, Kauffman HM. Living kidney donors in need of kidney transplants: a report from the organ procurement and transplantation network. Transplantation. 2002;74(9):1349-51.

34. Strifler L, Morris SK, Dang V, Tu HAT, Minhas RS, Jamieson FB, et al. The health burden of invasive meningococcal disease: a systematic review. J Pediatric Infect Dis Soc. 2016;5(4):417-30.

35. Eschbach JW. Hematologic problems of dialysis patients. In: Replacement of renal function by dialysis. Dordrecht: Springer Netherlands; 1979. p. 557-70.

36. Wanner C, Amann K, Shoji T. The heart and vascular system in dialysis. Lancet. 2016;388(10041):276-84.

37. Mason C, Dunnill P. A brief definition of regenerative medicine. Regen Med. 2008;3(1):1-5.

38. Humes HD, Fissell WH, Weitzel WF, Buffington DA, Westover AJ, MacKay SM, et al. Metabolic replacement of kidney function in uremic animals with a bioartificial kidney containing human cells. Am J Kidney Dis. 2002;39(5):1078-87.

39. Humes HD, Buffington DA, Mackay SM, Funke AJ, Weitzel WF. Replacement of renal function in uremic animals with a tissue- engineered kidney. Nat Biotechnol. 1999;17(5):451-5.

40. Humes HD, Weitzel WF, Bartlett RH, Swaniker FC, Paganini EP, Luderer JR, et al. Initial clinical results of the bioartificial kidney containing human cells in ICU patients with acute renal failure. Kidney Int. 2004;66(4):1578-88.

41. Madariaga MLL, Ott HC. Bioengineering kidneys for transplantation. Semin Nephrol. 2014;34(4):384-93

42. Buffington DA, Westover AJ, Johnston KA, Humes HD. The bioartificial kidney. Transl Res. 2014;163(4):342-51

43. Westover AJ, Buffington DA, Humes HD. Enhanced propagation of adult human renal epithelial progenitor cells to improve cell sourcing for tissueengineered therapeutic devices for renal diseases. J Tissue Eng Regen Med. 2012;8:589-7.
44. Buffington DA, Pino CJ, Chen L, Westover AJ, Hageman G, Humes HD. Bioartificial Renal Epithelial Cell System (BRECS): a compact, cryopreservable extracorporeal renal replacement device. Cell Med. 2012;4(1):33-44.

45. Pino CJ, Westover AJ, Buffington DA, Humes HD. Bioengineered renal cell therapy device for clinical translation. ASAIO J. 2017;63(3):305-15.

46. Westover AJ, Buffington DA, Johnston KA, Smith PL, Pino CJ, Humes HD. A bio-artificial renal epithelial cell system conveys survival advantage in a porcine model of septic shock. J Tissue Eng Regen Med. 2017;11(3):649-57.

47. Meng F, Seredych M, Chen C, Gura V, Mikhalovsky S, Sandeman S, et al. MXene sorbents for removal of urea from dialysate: a step toward the wearable artificial kidney. ACS Nano. 2018;12(10):10518-28.

48. Naguib M, Kurtoglu M, Presser V, Lu J, Niu J, Heon M, et al. Twodimensional nanocrystals produced by exfoliation of Ti3AIC2. Adv Mater. 2011;23(37):4248-53.

49. Castro AC, Neri M, Nayak Karopadi A, Lorenzin A, Marchionna N, Ronco C. Wearable artificial kidney and wearable ultrafiltration device vascular access_future directions. Clin Kidney J. 2018:12(2):200-307.

50. Canaud B, My H, Morena M, Lamy-Lacavalerie B, Leray-Moragues H, Bosc J, et al. Dialock: a new vascular access device for extracorporeal renal replacement therapy. Preliminary clinical results. Nephrol Dial Transplant. 1999;14(3):692-8.

51. Canaud B, Levin N, Ing T, My H, Dubrow AJ, Polaschegg HD, et al. Dialock: pilot trial of a new vascular port access device for hemodialysis. Semin Dial. 2008;12(5):382-8.

52. Schwab SJ, Weiss MA, Rushton F, Ross JP, Jackson J, Kapoian T, et al. Multicenter clinical trial results with the LifeSite ${ }^{\circledast}$ hemodialysis access system. Kidney Int. 2002;62(3):1026-33.

53. Beathard GA, Posen GA. Initial clinical results with the LifeSite ${ }^{\circledast}$ Hemodialysis Access System. Kidney Int. 2000;58(5):2221-7.

54. Rosenblatt M, Caridi JG, Hakki FZ, Jackson J, Kapoian T, Martin SP, et al. Efficacy and safety results with the LifeSite Hemodialysis Access System versus the Tesio-Cath hemodialysis catheter at 12 months. J Vasc Interv Radiol. 2006;17(3):497-504

55. Gura V, Rivara MB, Bieber S, Munshi $R$, Smith $N C$, Linke $L$, et al. A wearable artificial kidney for patients with end-stage renal disease. JCI Insight. 2016; 1(8):1-15.

56. Destefani AC, Sirtoli GM, Nogueira BV. Advances in the knowledge about kidney decellularization and repopulation. Front Bioeng Biotechnol. 2017;5:1-28.

57. Caralt M, Uzarski JS, lacob S, Obergfell KP, Berg N, Bijonowski BM, et al. Optimization and critical evaluation of decellularization strategies to develop renal extracellular matrix scaffolds as biological templates for organ engineering and transplantation. Am J Transplant. 2015;15(1):64-75.

58. Song JJ, Guyette JP, Gilpin SE, Gonzalez G, Vacanti JP, Ott HC. Regeneration and experimental orthotopic transplantation of a bioengineered kidney. Nat Med. 2013;19(5):646-51.

59. Poulsom R, Alison MR, Cook T, Jeffery R, Ryan E, Forbes SJ, et al. Hepatocyte growth factor prevents the development of chronic allograft nephropathy in rats. J Am Soc Nephrol. 2003;12(6):1280-92.

60. Poulsom R, Alison MR, Cook T, Jeffery R, Ryan E, Forbes SJ, et al. Bone marrow stem cells contribute to healing of the kidney. JASN. 2003;14:S48-54.

61. Hopkins C, Li J, Rae F, Little MH. Stem cell options for kidney disease. J Pathol. 2009;217:265-81.

62. Reis LA, Borges FT, Simões MJ, Borges AA, Sinigaglia-Coimbra R, Schor N. Bone marrow-derived mesenchymal stem cells repaired but did not prevent gentamicin-induced acute kidney injury through paracrine effects in rats. PLoS One. 2012;7(9):e44092 Camussi G, editor.

63. Bruno S, Grange C, Collino F, Deregibus MC, Cantaluppi V, Biancone L, et al. Microvesicles derived from mesenchymal stem cells enhance survival in a lethal model of acute kidney injury. PLoS One. 2012;7(3):e33115 Câmara NOS, editor.

64. Borges FT, Schor N. Regenerative medicine in kidney disease: where we stand and where to go. Pediatr Nephrol. 2018;33(9):1457-65.

65. Davies OG, Rafiq QA. Considerations for the bioprocessing, manufacture and translation of extracellular vesicles for therapeutic and diagnostic applications. Cell Gene Ther Insights. 2017;3(6):683-94.

66. Eiró N, Sendon-Lago J, Seoane S, Bermúdez MA, Lamelas ML, GarciaCaballero T, et al. Potential therapeutic effect of the secretome from human uterine cervical stem cells against both cancer and stromal cells compared with adipose tissue stem cells. Oncotarget. 2014;5(21):10692-708.

67. Bermudez MA, Sendon-Lago J, Eiro N, Trevino M, Gonzalez F, Yebra-

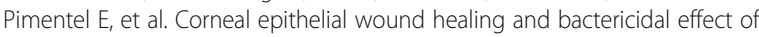


conditioned medium from human uterine cervical stem cells. Invest Ophthalmol Vis Sci. 2015;56(2):983-92.

68. Bermudez MA, Sendon-Lago J, Seoane S, Eiro N, Gonzalez F, Saa J, et al. Anti-inflammatory effect of conditioned medium from human uterine cervical stem cells in uveitis. Exp Eye Res. 2016;149:84-92.

69. Vizoso FJ, Eiro N, Cid S, Schneider J, Perez-Fernandez R. Mesenchymal stem cell secretome: toward cell-free therapeutic strategies in regenerative medicine. Int J Mol Sci. 2017;18(9):1852-76.

70. Tajiri S, Yamanaka S, Fujimoto T, Matsumoto K, Taguchi A, Nishinakamura R, et al. Regenerative potential of induced pluripotent stem cells derived from patients undergoing haemodialysis in kidney regeneration. Sci Rep. 2018; 8(1):14919.

71. Yamamoto M, Cui L, Johkura K, Asanuma K, Okouchi Y, Ogiwara N, et al. Branching ducts similar to mesonephric ducts or ureteric buds in teratomas originating from mouse embryonic stem cells. Am J Physiol Ren Physiol. 2006;290(1):F52-60.

72. Kim K, Doi A, Wen B, Ng K, Zhao R, Cahan P, et al. Epigenetic memory in induced pluripotent stem cells. Nature. 2010;467(7313):285-90.

73. Hu Q, Friedrich AM, Johnson LV, Clegg DO. Memory in induced pluripotent stem cells: reprogrammed human retinal-pigmented epithelial cells show tendency for spontaneous redifferentiation. Stem Cells. 2010;28(11):1981-91.

74. Zheng YL. Some ethical concerns about human induced pluripotent stem cells. Sci Eng Ethics. 2016;22(5):1277-84.

75. Becherucci F, Mazzinghi B, Allinovi M, Angelotti ML, Romagnani $P$. Regenerating the kidney using human pluripotent stem cells and renal progenitors. Expert Opin Biol Ther. 2018;18(7):795-806.

76. Haque MO. Saving behavior of university students. Actual Probl Econ. 2011; 126:409-19.

77. Nakamura M, Iwanaga S, Henmi C, Arai K, Nishiyama Y. Biomatrices and biomaterials for future developments of bioprinting and biofabrication. Biofabrication. 2010;2(1):1-6.

78. Mironov V, Visconti RP, Kasyanov V, Forgacs G, Drake CJ, Markwald RR. Organ printing: tissue spheroids as building blocks. Biomaterials. 2009; 30(12):2164-74.

79. Murphy SV, Atala A. 3D bioprinting of tissues and organs. Nat Biotechnol. 2014;32(8):773-85

80. Marga F, Neagu A, Kosztin I, Forgacs G. Developmental biology and tissue engineering. Birth Defects Res C Embryo Today. 2007;81:320-8.

81. Derby B. Printing and prototyping of tissues and scaffolds. Science. 2012; 338(6109):921-6.

82. Kelm JM, Lorber V, Snedeker JG, Schmidt D, Broggini-Tenzer A, Weisstanner $M$, et al. A novel concept for scaffold-free vessel tissue engineering: Selfassembly of microtissue building blocks. J Biotechnol. 2010;148(1):46-55.

83. Zhang B, Luo Y, Ma L, Gao L, Li Y, Xue Q, et al. $3 D$ bioprinting: an emerging technology full of opportunities and challenges. Biodess Manuf. 2018;1(1):2-13.

84. Ozbolat IT. Bioprinting scale-up tissue and organ constructs for transplantation. Trends Biotechnol. 2015;33(7):395-400.

85. Zhang YS, Yue K, Aleman J, Mollazadeh-Moghaddam K, Bakht SM, Yang J, et al. 3D bioprinting for tissue and organ fabrication. Ann Biomed Eng. 2017:45(1):148-63.

86. Mandrycky C, Wang Z, Kim K, D-HH K. 3D bioprinting for engineering complex tissues. Biotechnol Adv. 2016;34(4):422-34.

87. Xu F, Moon S, Emre AE, Lien C, Turali ES, Demirci U. Cell bioprinting as a potential high-throughput method for fabricating cell-based biosensors (CBBs). In: Sensors, 2009 IEEE. Christchurch: IEEE; 2009. p. 387-91.

88. Tasoglu S, Demirci U. Bioprinting for stem cell research. Trends Biotechnol. 2013;31(1):10-9.

89. Derakhshanfar S, Mbeleck R, Xu K, Zhang X, Zhong W, Xing M. 3D bioprinting for biomedical devices and tissue engineering: a review of recent trends and advances. Bioact Mater. 2018;3(2):144-56.

90. Gauvin R, Chen Y-CC, Lee JW, Soman P, Zorlutuna P, Nichol JW, et al. Microfabrication of complex porous tissue engineering scaffolds using 3D projection stereolithography. Biomaterials. 2012;33(15):3824-34.

91. Gou M, Qu X, Zhu W, Xiang M, Yang J, Zhang K, et al. Bio-inspired detoxification using 3D-printed hydrogel nanocomposites. Nat Commun. 2014:5:3774

92. Elomaa L, Teixeira S, Hakala R, Korhonen H, Grijpma DW, Seppälä JV. Preparation of poly( $\varepsilon$-caprolactone)-based tissue engineering scaffolds by stereolithography. Acta Biomater. 2011;7(11):3850-6.

93. Ovsianikov A, Deiwick A, Van Vlierberghe S, Dubruel P, Möller L, Drager G, et al. Laser fabrication of three-dimensional CAD scaffolds from photosensitive gelatin for applications in tissue engineering. Biomacromolecules. 2011;12(4):851-8.

94. Tekin E, Smith PJ, Schubert US. Inkjet printing as a deposition and patterning tool for polymers and inorganic particles. Soft Matter. 2008;4(4):703-13.

95. Khalil S, Sun W. Biopolymer deposition for freeform fabrication of hydrogel tissue constructs. Mater Sci Eng C. 2007;27(3):469-78.

96. Murphy SV, Skardal A, Atala A. Evaluation of hydrogels for bio-printing applications. J Biomed Mater Res Part A. 2013;101(1):272-84.

97. Muntean A, Lucan M. Immunosuppression in kidney transplantation. Clujul Med. 2013;86(3):177-80.

98. Jiao A, Trosper NE, Yang HS, Kim J, Tsui JH, Frankel SD, et al. Thermoresponsive nanofabricated substratum for the engineering of threedimensional tissues with layer-by-layer architectural control. ACS Nano. 2014;8(5):4430-9.

99. Kim HN, Jiao A, Hwang NS, Kim MS, Kang DH, D-HH K, et al. Nanotopography-guided tissue engineering and regenerative medicine. Adv Drug Deliv Rev. 2013;65(4):536-58.

100. Kim P, Yuan A, Nam K-HH, Jiao A, Kim D-HH. Fabrication of poly (ethylene glycol): gelatin methacrylate composite nanostructures with tunable stiffness and degradation for vascular tissue engineering. Biofabrication. 2014;6(2):1-12.

101. Shapira A, Kim D-H, Dvir T. Advanced micro-and nanofabrication technologies for tissue engineering. Biofabrication. 2014;6(2):2-5.

102. Schuurman W, Khristov V, Pot MW, Van Weeren PR, Dhert WJA, Malda J. Bioprinting of hybrid tissue constructs with tailorable mechanical properties. Biofabrication. 2011;3(2):1-7.

103. Duan B, Hockaday LA, Kang KH, Butcher JT. 3D bioprinting of heterogeneous aortic valve conduits with alginate/gelatin hydrogels. J Biomed Mater Res Part A. 2013;101 A(5):1255-64.

104. Shanjani Y, Pan CC, Elomaa L, Yang Y. A novel bioprinting method and system for forming hybrid tissue engineering constructs. Biofabrication. 2015;7(4):1-16.

105. 3Dynamic Systems Ltd. Bioprinter Omega | 3Dynamic Systems Ltd. 2019. Available from: http://www.bioprintingsystems.com/bioprinter-omega.html. Cited 2019 Feb 15

106. Tumbleston JR, Shirvanyants D, Ermoshkin N, Janusziewicz $R$, Johnson AR, Kelly D, et al. Continuous liquid interface production of 3D objects. Science. 2015;347(6228):1349-52.

107. Ozbolat IT, Moncal KK, Gudapati H. Evaluation of bioprinter technologies. Addit Manuf. 2017;13:179-200

108. Pati F, Gantelius J, Svahn HA. 3D bioprinting of tissue/organ models. Angew Chem Int Ed. 2016;55(15):4650-65.

109. Jakab K, Marga F, Norotte C, Forgacs G. 4. The promises of tissue engineering for organ building and banking. Cryobiology. 2015;71(1):165-6.

110. Ji S, Guvendiren M. Recent advances in bioink design for 3D bioprinting of tissues and organs. Front Bioeng Biotechnol. 2017;5(23):1-8.

111. Yabu JM, Siebert JC, Maecker HT. Immune profiles to predict response to desensitization therapy in highly HLA-sensitized kidney transplant candidates. Stepkowski S, editor PLoS One 2016;11(4):1-16.

112. Cucchiari D, Podestà MA, Ponticelli $C$. The critical role of innate immunity in kidney transplantation. Nephron. 2016;132(3):227-37.

113. Jose RR, Rodriguez MJ, Dixon TA, Omenetto F, Kaplan DL. Evolution of bioinks and additive manufacturing technologies for 3D bioprinting. ACS Biomater Sci Eng. 2016;2(10):1662-78.

114. Munaz A, Vadivelu RK, John JS, Barton M, Kamble H, Nguyen N-T. Threedimensional printing of biological matters. J Sci Adv Mater Devices. 2016;1(1):1-17.

115. Kim E-SS, Ahn EH, Dvir T, Kim D-HH. Emerging nanotechnology approaches in tissue engineering and regenerative medicine. Int J Nanomedicine. 2014; 9(Suppl 1):1-5.

116. Shin SR, Jung SM, Zalabany M, Kim K, Zorlutuna P, Kim SB, et al. Carbonnanotube-embedded hydrogel sheets for engineering cardiac constructs and bioactuators. ACS Nano. 2013;7(3):2369-80.

117. Zhang $X, X u B$, Puperi DS, Yonezawa AL, Wu Y, Tseng $H$, et al. Integrating valve-inspired design features into poly (ethylene glycol) hydrogel scaffolds for heart valve tissue engineering. Acta Biomater. 2015;14:11-21.

118. Zustiak SP, Leach JB. Hydrolytically degradable poly (ethylene glycol) hydrogel scaffolds with tunable degradation and mechanical properties. Biomacromolecules. 2010;11(5):1348-57.

119. Bajaj P, Schweller RM, Khademhosseini A, West JL, Bashir R. 3D biofabrication strategies for tissue engineering and regenerative medicine. Annu Rev Biomed Eng. 2014;16:247-76. 
120. Hölzl K, Lin S, Tytgat L, Van Vlierberghe S, Gu L, Ovsianikov A. Bioink properties before, during and after 3D bioprinting. Biofabrication. 2016;8(3): $1-19$.

121. Elbert DL. Bottom-up tissue engineering. Curr Opin Biotechnol. 2011;22(5): 674-80.

122. Leijten J, Rouwkema J, Zhang YS, Nasajpour A, Dokmeci MR, Khademhosseini A. Advancing tissue engineering: a tale of nano-, micro-, and macroscale integration. Small. 2016;12(16):2130-45.

123. Zhang YS, Aleman J, Arneri A, Bersini S, Piraino F, Shin SR, et al. From cardiac tissue engineering to heart-on-a-chip: beating challenges. Biomed Mater. 2015;10(3):1-21

124. Ren X, Moser PT, Gilpin SE, Okamoto T, Wu T, Tapias LF, et al. Engineering pulmonary vasculature in decellularized rat and human lungs. Nat Biotechnol. 2015;33(10):1097-102

125. Campbell PG, Weiss LE. Tissue engineering with the aid of inkjet printers. Expert Opin Biol Ther. 2007;7(8):1123-7.

126. Cui X, Breitenkamp K, Finn MG, Lotz M, D'Lima DD. Direct human cartilage repair using three-dimensional bioprinting technology. Tissue Eng Part A. 2012;18(11-12):1304-12.

127. Kolesky DB, Truby RL, Gladman AS, Busbee TA, Homan KA, Lewis JA. 3D bioprinting of vascularized, heterogeneous cell-laden tissue constructs. Adv Mater. 2014;26(19):3124-30

128. Lee VK, Kim DY, Ngo H, Lee Y, Seo L, S-SS Y, et al. Creating perfused functional vascular channels using 3D bio-printing technology. Biomaterials. 2014;35(28):8092-102.

129. Miller JS, Stevens KR, Yang MT, Baker BM, Nguyen D-HTHT, Cohen DM, et al. Rapid casting of patterned vascular networks for perfusable engineered three-dimensional tissues. Nat Mater. 2012;11(9):768-74.

130. Hinton TJ, Jallerat Q, Palchesko RN, Park JH, Grodzicki MS, H-JJ S, et al. Three-dimensional printing of complex biological structures by freeform reversible embedding of suspended hydrogels. Sci Adv. 2015;1(9):1-10.

131. Bertassoni LE, Cecconi M, Manoharan V, Nikkhah M, Hjortnaes J, Cristino AL, et al. Hydrogel bioprinted microchannel networks for vascularization of tissue engineering constructs. Lab Chip. 2014;14(13):2202-11.

132. Taylor RE, Kim K, Sun N, Park S-JJ, Sim JY, Fajardo G, et al. Sacrificial layer technique for axial force post assay of immature cardiomyocytes. Biomed Microdevices. 2013;15(1):171-81.

133. Guillaumin S. One step closer for kidney tissue engineering - physics world 2018. Available from: https://physicsworld.com/a/one-step-closer-for-kidneytissue-engineering/. Cited 2019 Jan 4

134. van den Berg CW, Ritsma $L$, Avramut MC, Wiersma LE, van den Berg BM, Leuning DG, et al. Renal subcapsular transplantation of PSC-derived kidney organoids induces neo-vasculogenesis and significant glomerular and tubular maturation in vivo. Stem Cell Rep. 2018;10(3):751-65.

135. Lemme $M$, Ulmer BM, Lemoine MD, Zech ATL, Flenner F, Ravens $U$, et al. Atrial-like engineered heart tissue: an in vitro model of the human atrium. Stem Cell Rep. 2018;11(6):1378-90.

136. Benam KH, Dauth S, Hassell B, Herland A, Jain A, Jang K-J, et al. Engineered in vitro disease models. Annu Rev Pathol Mech Dis. 2015;10:195-262.

137. Jackman CP, Shadrin IY, Carlson AL, Bursac N. Human cardiac tissue engineering: from pluripotent stem cells to heart repair. Curr Opin Chem Eng. 2015;7:57-64.

138. Bhatia SN, Ingber DE. Microfluidic organs-on-chips. Nat Biotechnol. 2014; 32(8):760-72.

139. Khademhosseini A, Langer R, Borenstein J, Vacanti JP. Microscale technologies for tissue engineering and biology. Proc Natl Acad Sci U S A. 2006;103(8):2480-7.

140. Place ES, Evans ND, Stevens MM. Complexity in biomaterials for tissue engineering. Nat Mater. 2009;8(6):457-70.

141. Niklason LE, Gao J, Abbott WM, Hirschi KK, Houser S, Marini R, et al. Functional arteries grown in vitro. Science. 1999;284(5413):489-93.

142. Ratcliffe A. Tissue engineering of vascular grafts. Matrix Biol. 2000;19(4):353-7.

143. Nunes SS, Miklas JW, Liu J, Aschar-Sobbi R, Xiao Y, Zhang B, et al. Biowire: a platform for maturation of human pluripotent stem cell-derived cardiomyocytes. Nat Methods. 2013;10(8):781-7.

144. Tandon N, Cannizzaro C, Chao P-HG, Maidhof R, Marsano A, Au HTH, et al. Electrical stimulation systems for cardiac tissue engineering. Nat Protoc. 2009:4(2):155-73.

145. Antlanger M, Reiter T, Lamm W, Rabitsch W, Gisslinger $H$, Agis $H$, et al. Does renal failure affect outcome after autologous stem cell transplantation in patients with multiple myeloma? Blood. 2016;128(22):1-11.
146. Dimri GP, Lee X, Basile G, Acosta M, Scott G, Roskelley C, et al. A biomarker that identifies senescent human cells in culture and in aging skin in vivo. Proc Natl Acad Sci. 1995;92(20):9363-7.

147. Oxburgh L, Carroll TJ. The bioengineered kidney: science or science fiction? Curr Opin Nephrol Hypertens. 2016;25(4):343-7.

148. Mammoto T, Mammoto A, Ingber DE. Mechanobiology and developmental control. Annu Rev Cell Dev Biol. 2013;29(1):27-61.

149. Taguchi A, Kaku Y, Ohmori T, Sharmin S, Ogawa M, Sasaki H, et al. Redefining the in vivo origin of metanephric nephron progenitors enables generation of complex kidney structures from pluripotent stem cells. Cell Stem Cell. 2014;14(1):53-67.

150. Herzlinger D, Koseki C, Mikawa T, al-Awqati Q. Metanephric mesenchyme contains multipotent stem cells whose fate is restricted after induction. Development. 1992;114(3):565-72.

151. Self M, Lagutin OV, Bowling B, Hendrix J, Cai Y, Dressler GR, et al. Six2 is required for suppression of nephrogenesis and progenitor renewal in the developing kidney. EMBO J. 2006;25(21):5214-28.

152. Kobayashi A, Valerius MT, Mugford JW, Carroll TJ, Self M, Oliver G, et al. Six2 defines and regulates a multipotent self-renewing nephron progenitor population throughout mammalian kidney development. Cell Stem Cell. 2008:3(2):169-81.

153. Boyle S, Misfeldt A, Chandler KJ, Deal KK, Southard-Smith EM, Mortlock DP, et al. Fate mapping using Cited1-CreERT2 mice demonstrates that the cap mesenchyme contains self-renewing progenitor cells and gives rise exclusively to nephronic epithelia. Dev Biol. 2008;313(1):234-45.

154. Taguchi A, Nishinakamura R. Higher-order kidney organogenesis from pluripotent stem cells. Cell Stem Cell. 2017;21(6):730-746.e6.

155. Morizane R, Monkawa T, Fujii S, Yamaguchi S, Homma K, Matsuzaki Y, et al. Kidney specific protein-positive cells derived from embryonic stem cells reproduce tubular structures in vitro and differentiate into renal tubular cells. PLoS One. 2013;8(6):e64843 Nichols J, editor.

156. Takasato M, Er PX, Chiu HS, Maier B, Baillie GJ, Ferguson C, et al. Kidney organoids from human iPS cells contain multiple lineages and model human nephrogenesis. Nature. 2015;526(7574):564-8.

157. De Coppi P, Bartsch G, Siddiqui MM, Xu T, Santos CC, Perin L, et al. Isolation of amniotic stem cell lines with potential for therapy. Nat Biotechnol. 2007;25(1):100-6.

158. Murphy S, Rosli S, Acharya R, Mathias L, Lim R, Wallace E, et al. Amnion epithelial cell isolation and characterization for clinical use. Curr Protoc Stem Cell Biol. 2010;13(1):1-6.

159. Song B, Niclis JC, Alikhan MA, Sakkal S, Sylvain A, Kerr PG, et al. Generation of induced pluripotent stem cells from human kidney mesangial cells. J Am Soc Nephrol. 2011;22(7):1213-20

160. Song B, Smink AM, Jones CV, Callaghan JM, Firth SD, Bernard CA, et al. The directed differentiation of human iPS cells into kidney podocytes. PLoS One. 2012;7(9):e46453 Rastaldi MP, editor.

161. Montserrat N, Ramírez-Bajo MJ, Xia Y, Sancho-Martinez I, Moya-Rull D, Miquel-Serra L, et al. Generation of induced pluripotent stem cells from human renal proximal tubular cells with only two transcription factors, Oct4 and Sox2. J Biol Chem. 2012;287(29):24131-8.

162. Zhou T, Benda C, Dunzinger S, Huang Y, Ho JC, Yang J, et al. Generation of human induced pluripotent stem cells from urine samples. Nat Protoc. 2012;7(12):2080-9.

163. Hendry CE, Vanslambrouck JM, Ineson J, Suhaimi N, Takasato M, Rae F, et al. Direct transcriptional reprogramming of adult cells to embryonic nephron progenitors. J Am Soc Nephrol. 2013;24(9):1424-34.

164. Mae S-I, Ryosaka M, Toyoda T, Matsuse K, Oshima Y, Tsujimoto H, et al. Generation of branching ureteric bud tissues from human pluripotent stem cells. Biochem Biophys Res Commun. 2018;495(1):954-61.

165. Oxburgh L, Carroll TJ, Cleaver O, Gossett DR, Hoshizaki DK, Hubbell JA, et al. (Re)Building a kidney. J Am Soc Nephrol. 2017;28(5):1370-8.

166. Lu T, Li Y, Chen T. Techniques for fabrication and construction of threedimensional scaffolds for tissue engineering. Int J Nanomedicine. 2013;8:337-50.

167. Guillemot F, Souquet A, Catros S, Guillotin B, Lopez J, Faucon M, et al. Highthroughput laser printing of cells and biomaterials for tissue engineering. Acta Biomater. 2010;6(7):2494-500.

168. Pepper ME, Seshadri V, Burg TC, Burg KJL, Groff RE. Characterizing the effects of cell settling on bioprinter output. Biofabrication. 2012;4(1):11001

169. Pepper ME, Seshadri V, Burg T, Booth BW, Burg KJLL, Groff RE. Cell settling effects on a thermal inkjet bioprinter. In: Engineering in medicine and biology society, EMBC, 2011 annual international conference of the IEEE. Boston: IEEE; 2011. p. 3609-12. 
170. Xu T, Jin J, Gregory C, Hickman JJ, Boland T. Inkjet printing of viable mammalian cells. Biomaterials. 2005;26(1):93-9.

171. Ciancio G, Sageshima J, Akpinar E, Gaynor JJ, Chen L, Zarak A, et al. A randomized pilot study of donor stem cell infusion in living-related kidney transplant recipients receiving alemtuzumab. Transp J. 2013;96(9):800-6.

172. Morizane R, Lam AQ, Freedman BS, Kishi S, Valerius MT, Bonventre JV. Nephron organoids derived from human pluripotent stem cells model kidney development and injury. Nat Biotechnol. 2015:33(11):1193-200.

173. Unbekandt M, Davies JA. Dissociation of embryonic kidneys followed by reaggregation allows the formation of renal tissues. Kidney Int. 2010;77(5):407-16.

174. Xinaris C, Benedetti V, Rizzo P, Abbate M, Corna D, Azzollini N, et al. In vivo maturation of functional renal organoids formed from embryonic cell suspensions. J Am Soc Nephrol. 2012:23(11):1857-68.

175. Freedman BS, Brooks CR, Lam AQ, Fu H, Morizane R, Agrawal V, et al. Modelling kidney disease with CRISPR-mutant kidney organoids derived from human pluripotent epiblast spheroids. Nat Commun. 2015;6(1):1-13.

176. Clevers H. Modeling development and disease with organoids. Cell. 2016; 165(7):1586-97.

177. Dutta D, Heo I, Clevers H. Disease modeling in stem cell-derived $3 D$ organoid systems. Trends Mol Med. 2017;23(5):393-410.

178. Astashkina Al, Mann BK, Prestwich GD, Grainger DW. A 3-D organoid kidney culture model engineered for high-throughput nephrotoxicity assays. Biomaterials. 2012;33(18):4700-11.

179. Wilmer MJ, Ng CP, Lanz HL, Vulto P, Suter-Dick L, Masereeuw R. Kidney-ona-chip technology for drug-induced nephrotoxicity screening. Trends Biotechnol. 2016;34(2):156-70.

180. Mckee RA, Wingert RA. Repopulating decellularized kidney scaffolds: an avenue for ex vivo organ generation. Mater (Basel, Switzerland). 2016;9(3):1-11.

181. Badylak SF, Taylor D, Uygun K. Whole-organ tissue engineering: decellularization and recellularization of three-dimensional matrix scaffolds. Annu Rev Biomed Eng. 2011;13(1):27-53.

182. Arenas-Herrera JE, Ko IK, Atala A, Yoo JJ. Decellularization for whole organ bioengineering. Biomed Mater. 2013;8(1):1-10.

183. Poornejad N, Momtahan N, Salehi ASM, Scott DR, Fronk CA, Roeder BL, et al. Efficient decellularization of whole porcine kidneys improves reseeded cell behavior. Biomed Mater. 2016;11(2):1-15.

184. Badylak SF. Xenogeneic extracellular matrix as a scaffold for tissue reconstruction. Transpl Immunol. 2004;12(3-4):367-77.

185. Choi SH, Chun SY, Chae SY, Kim JR, Oh SH, Chung SK, et al. Development of a porcine renal extracellular matrix scaffold as a platform for kidney regeneration. J Biomed Mater Res Part A. 2015;103(4):1391-403.

186. Xia Y, Nivet E, Sancho-Martinez I, Gallegos T, Suzuki K, Okamura D, et al. Directed differentiation of human pluripotent cells to ureteric bud kidney progenitor-like cells. Nat Cell Biol. 2013;15(12):1507-15.

187. Nakayama KH, Batchelder CA, Lee Cl, Tarantal AF. Renal tissue engineering with decellularized rhesus monkey kidneys: age-related differences. Tissue Eng Part A. 2011;17(23-24):2891-901.

188. Hussein KH, Saleh T, Ahmed E, Kwak H-H, Park K-M, Yang S-R, et al. Biocompatibility and hemocompatibility of efficiently decellularized whole porcine kidney for tissue engineering. J Biomed Mater Res Part A. 2018; 106(7):2034-47.

189. Sullivan DC, Mirmalek-Sani S-H, Deegan DB, Baptista PM, Aboushwareb T, Atala A, et al. Decellularization methods of porcine kidneys for whole organ engineering using a high-throughput system. Biomaterials. 2012;33(31):7756-64.

190. Yu YL, Shao YK, Ding YQ, Lin KZ, Chen B, Zhang HZ, et al. Decellularized kidney scaffold-mediated renal regeneration. Biomaterials. 2014;35(25):6822-8.

191. Khan A, Vishwakarma S, Bhavani P, Bardia A, Abkari A, Murthy GSN, et al. Preparation of natural three-dimensional goat kidney scaffold for the development of bioartificial organ. Indian J Nephrol. 2014;24(6):372-5.

192. Orlando G, Farney AC, Iskandar SS, Mirmalek-Sani S-H, Sullivan DC, Moran E, et al. Production and implantation of renal extracellular matrix scaffolds from porcine kidneys as a platform for renal bioengineering investigations. Ann Surg. 2012;256(2):363-70.

193. Orlando G, Booth C, Wang Z, Totonelli G, Ross CL, Moran E, et al. Discarded human kidneys as a source of ECM scaffold for kidney regeneration technologies. Biomaterials. 2013;34(24):5915-25.

194. Faulk DM, Johnson SA, Zhang L, Badylak SF. Role of the extracellular matrix in whole organ engineering. J Cell Physiol. 2014;229(8):984-9.

195. Faulk DM, Wildemann JD, Badylak SF. Decellularization and cell seeding of whole liver biologic scaffolds composed of extracellular matrix. J Clin Exp Hepatol. 2015;5(1):69-80.
196. Lih E, Park KW, Chun SY, Kim H, Kwon TG, Joung YK, et al. Biomimetic porous PLGA scaffolds incorporating decellularized extracellular matrix for kidney tissue regeneration. ACS Appl Mater Interfaces. 2016;8(33):21145-54.

197. Ross EA, Williams MJ, Hamazaki T, Terada N, Clapp WL, Adin C, et al. Embryonic stem cells proliferate and differentiate when seeded into kidney scaffolds. J Am Soc Nephrol. 2009;20(11):2338-47.

198. Bonandrini B, Figliuzzi M, Papadimou E, Morigi M, Perico N, Casiraghi F, et al. Recellularization of well-preserved acellular kidney scaffold using embryonic stem cells. Tissue Eng Part A. 2014;20(9-10):1486-98.

199. Guan Y, Liu S, Sun C, Cheng G, Kong F, Luan Y, et al. The effective bioengineering method of implantation decellularized renal extracellular matrix scaffolds. Oncotarget. 2015;6(34):36126-38.

200. O'Neill JD, Freytes DO, Anandappa AJ, Oliver JA, Vunjak-Novakovic GV. The regulation of growth and metabolism of kidney stem cells with regional specificity using extracellular matrix derived from kidney. Biomaterials. 2013; 34(38):9830-41.

201. Melchels FPWW, Domingos MANN, Klein TJ, Malda J, Bartolo PJ, Hutmacher DW. Additive manufacturing of tissues and organs. Prog Polym Sci. 2012; 37(8):1079-104.

202. Yoo S-S. 3D-printed biological organs: medical potential and patenting opportunity. Expert Opin Ther Pat. 2015;25(5):507-11.

203. Park H, Cannizzaro C, Vunjak-Novakovic G, Langer R, Vacanti CA, Farokhzad OC. Nanofabrication and microfabrication of functional materials for tissue engineering. Tissue Eng. 2007:13(8):1867-77.

204. Rodell CB, MacArthur JW, Dorsey SM, Wade RJ, Wang LL, Woo YJ, et al. Shear-thinning supramolecular hydrogels with secondary autonomous covalent crosslinking to modulate viscoelastic properties in vivo. Adv Funct Mater. 2015:25(4):636-44.

205. Gladman AS, Matsumoto EA, Nuzzo RG, Mahadevan L, Lewis JA. Biomimetic 4D printing. Nat Mater. 2016;15(4):413.

Ready to submit your research? Choose BMC and benefit from

- fast, convenient online submission

- thorough peer review by experienced researchers in your field

- rapid publication on acceptance

- support for research data, including large and complex data types

- gold Open Access which fosters wider collaboration and increased citations

- maximum visibility for your research: over $100 \mathrm{M}$ website views per year

At $\mathrm{BMC}$, research is always in progress.

Learn more biomedcentral.com/submissions 